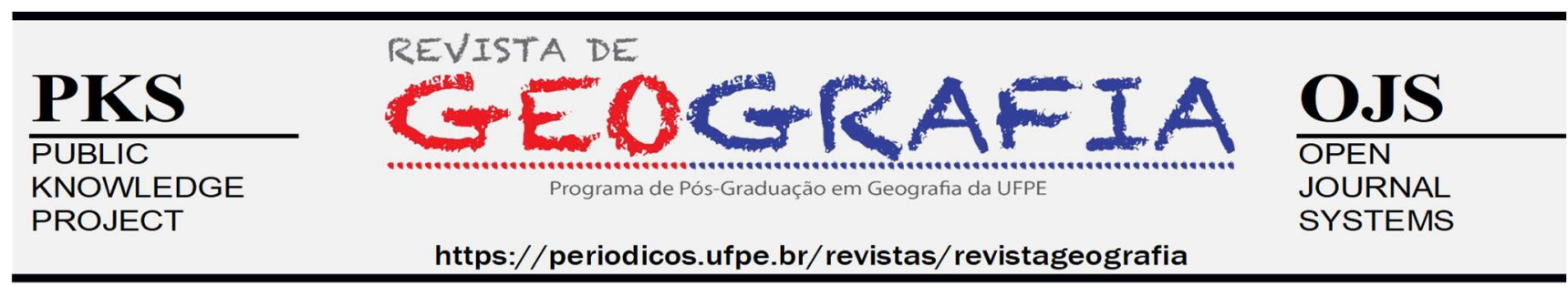

\title{
A CONTEXTUALIZAÇÃO DO PMCMV EM UMA CIDADE MÉDIA: NOVA CONFIGURAÇÃO TERRITORIAL E IMPACTO SOCIOESPACIAL NO CONJUNTO SANTA JÚLIA EM MOSSORÓ-RN
}

\author{
Cleiton Ferreira da Silva ${ }^{1}$ \\ ${ }^{1}$ Pós-Doutorando do Grupo de Pesquisa Produção do Espaço e Redefinições Regionais (GAsPERR), Universidade \\ Estadual Paulista (UNESP) - Presidente Prudente, SP. E-mail: cleitonf4@yahoo.com.br
}

Artigo recebido em 04/09/2020 e aceito em 13/12/2020

\begin{abstract}
RESUMO
Este texto analisa a política pública de habitação popular, através do Programa Minha Casa Minha Vida (PMCMV) Faixa 1 na cidade de Mossoró, nordeste brasileiro. Pretende-se desta forma, analisar o padrão de provisão de moradias em uma cidade média e suas reais consequências para as famílias. A ideia aqui, portanto, é problematizar o padrão segmentado de expansão urbana para a população mais pobre, a caracterização das tipologias das habitações, a ausência de equipamentos públicos básicos, o perfil socioeconômico das famílias atendidas e, como isso impacta na habitabilidade e no cotidiano dos moradores do Conjunto Residencial Santa Júlia, objeto deste estudo. Para isso, foram realizadas análises de literatura, acesso aos dados de produção habitacional do PMCMV junto ao Ministério do Desenvolvimento Regional, questionários para a população residente e inserção de base cartográfica com raios de distância, do Conjunto Residencial para os principais equipamentos públicos oferecidos pelo Estado.
\end{abstract}

Palavras-chave: Cidades Médias; Política Habitacional; Configuração Territorial; PMCMV; Efeitos Socioespaciais.

\section{THE CONTEXTUALIZATION OF PMCMV IN A MIDDLE CITY: NEW TERRITORIAL CONFIGURATION AND SOCIO-SPATIAL IMPACT ON THE CONJUNTO SANTA JÚLIA IN MOSSORÓ-RN}

\begin{abstract}
This text analyzes the public policy of popular housing, through the Programa Minha Casa Minha Vida (PMCMV) Track 1 in the city of Mossoró, northeastern Brazil. In this way, the intention is to analyze the pattern of housing provision in an average city and its real consequences for families. The idea here, therefore, is to problematize the segmented pattern of urban expansion for the poorest population, the characterization of the types of housing, the absence of basic public facilities, the socioeconomic profile of the families served, and how this impacts on habitability and daily life of residents of Conjunto Residencial Santa Júlia, object of this study. For this purpose, literature analyzes, access to PMCMV housing production data were carried out with the Ministry of Regional Development, questionnaires for the resident population and insertion of cartographic base with distance rays, from the Residential Complex to the main public facilities offered by the State.
\end{abstract}

Keywords: Average Cities; Housing Policy; Territorial Configuration; PMCMV; Socio-spatial Effects 


\section{INTRODUÇÃO}

Este trabalho é resultante, das primeiras análises do Projeto de pesquisa Fragmentação socioespacial e urbanização brasileira (FragUrb) ${ }^{1}$, que vem investigando, em diversas cidades do Brasil, processos da urbanização contemporânea, a partir das seguintes dimensões empíricas: trabalhar, lazer, habitar, mobilidade e consumir ${ }^{2}$. Nosso foco aqui neste artigo, está centrado sob a perspectiva da dimensão habitar.

Localizada no oeste do estado do Rio Grande do Norte, nordeste brasileiro, a cidade de Mossoró é o segundo maior centro urbano do estado, onde possui importantes atividades econômicas como extração de petróleo, produção de sal e agricultura irrigada, que induzem a dinamização e o padrão de crescimento e expansão territorial, fortemente amparada também pelo poder público local. O resultado no setor produtivo, assim como na esfera habitacional, é o aumento de investimentos, tanto público quanto privado. No bojo da produção de moradias do PMCMV em Mossoró, este texto se propõe em caracterizar um dos empreendimentos na cidade, o Conjunto Residencial Santa Júlia, analisando sua espacialidade, padrão de habitabilidade, como vivem e o que pensam seus moradores.

Entregue no segundo semestre de 2015, o conjunto possui um padrão de periferização, com limitados serviços para a população, evidenciando baixíssimo grau de condições socioeconômicas para os moradores e sua respectiva habitabilidade, na ausência de áreas de lazer efetivas como praças e parques, serviços públicos como postos de saúde, creches e escolas, desencadeando um grau de fragmentação socioespacial, onde as famílias são submetidas cotidianamente. Reproduz-se assim, a lógica institucional e espacial recente de urbanização contemporânea nas cidades brasileiras.

Inicialmente, para a construção teórica deste trabalho, levou-se em consideração a análise da habitação sob a perspectiva do capitalismo em Harvey (1980), Shimbo (2010), Maricato (2001), Fix (2011) e Rolnik (2019), inserindo e caracterizando o PMCMV neste contexto, além de tematizar a restruturação do capital produtivo e a inserção de novas demandas de consumo e desenvolvimento em cidades médias com Silveira (2002), Sposito (2006), Corrêa (2007) e Damiani (2006). Para compreender os aspectos norteadores do programa, a dimensão da tipologia das habitações e seu funcionamento para a modalidade faixa 1 , objeto da pesquisa, foi proposto a sistematização a partir de Bonduki (2009), Cardoso e Aragão (2013) e Melazzo (2013).

\footnotetext{
${ }^{1}$ Trata-se do Projeto Temático Fragmentação socioespacial e urbanização brasileira: escalas, vetores, ritmos e formas (FragUrb), sob o financiamento da Fundação de Amparo à Pesquisa do Estado de São Paulo (FAPESP), processo: 18/07701-8, na qual Mossoró é uma das cidades pesquisadas.

${ }^{2}$ As dimensões empíricas trabalhadas no projeto, permitirão uma análise dos diferentes momentos e práticas espaciais que atingem de maneira desigual os citadinos.
}

$\begin{array}{lll}\text { Silva, } 2020 & \text { ISSN 0104-5490 } & 382\end{array}$


$\mathrm{Na}$ análise com moradores, baseou-se em Gil (1999), quando foram adotadas técnicas de confecção e aplicação de 40 questionários (múltipla escolha) para membros familiares que habitavam uma das casas (essencialmente beneficiárias do programa) ${ }^{3}$, num universo de 376 moradias do conjunto habitacional Santa Júlia. Esta análise totalizou 10,6\% dos representantes, com 20 questões entre perguntas abertas e fechadas. Foram acessados ainda, dados de produção habitacional do PMCMV junto ao Ministério do Desenvolvimento Regional, informações da Secretaria de Assistência Social da Prefeitura de Mossoró, sobre a origem dos bairros das famílias e; análise de itinerário da empresa de transporte público referente às linhas que atendem os moradores, com seu respectivo tempo de circulação. Por fim, o levantamento baseou-se em Souza e Leite (2019), na utilização de base cartográfica de raio de distância do conjunto para o posto de saúde, escolas mais próximas e na sistematização das informações, além de depoimentos dos moradores sobre o conjunto em página de rede social do conjunto.

Pretende-se desta forma, desenvolver a caracterização espacial do Santa Júlia e dos seus moradores, explicar à luz da análise crítica, o padrão de provisão de moradias em uma cidade média e suas reais consequências para as famílias, levando em consideração o modelo de política pública habitacional adotado para a construção do empreendimento e, sua efetiva ocupação.

\section{CAPITALISMO, ESPAÇO URBANO E HABITAÇÃO}

O espaço urbano é um verdadeiro mosaico de forças políticas, econômicas e sociais, que atuam permanentemente em favor dos seus interesses, ora individuais ora coletivos. Numa sociedade capitalista, apenas uma restrita e seleta parcela da população se beneficia das grandes obras ou grandes empreendimentos urbanos, ou seja, a classe detentora das condições objetivas de produção e consumo (HARVEY, 2005). Tal condição é evidenciada na forma seletiva que a população tem acesso aos serviços públicos de qualidade como saúde, educação, transporte e segurança. O espaço da moradia na cidade capitalista brasileira reflete também esta premissa, espaços hierarquizados, a partir das classes sociais que os reproduzem e os ocupam, isto é, favelas, loteamentos, empreendimentos imobiliários periféricos, fragmentados e segregados socioespacialmente para a população pobre e, condomínios fechados e prédios modernos para a população mais rica. Harvey (1980) sistematiza esta diferenciação residencial da seguinte forma:

\footnotetext{
${ }^{3}$ A aplicação dos questionários foi realizada com o suporte técnico de demais pesquisadores e colaboradores do projeto temático, durante o trabalho de campo na cidade de Mossoró em outubro de 2019.
} 
A diferenciação residencial deve ser interpretada em termos de reprodução das relações sociais dentro da sociedade capitalista; As áreas residenciais fornecem meios distintos para a interpretação social, a partir da qual os indivíduos derivam seus valores, expectativas, hábitos de consumo, capacidade de se fazer valer e estado de consciência; A diferenciação residencial significa acesso diferenciado a recursos escassos necessários para se adquirir oportunidades para ascensão social; Segregação quer dizer, diferenciação residencial segundo grupos, significa diferencial de renda real - proximidade às facilidades da vida urbana como água, esgoto, melhores serviços educacionais, etc. (HARVEY,1980, p. 210).

Recentemente, o setor imobiliário brasileiro se intensificou com o desenvolvimento do $\mathrm{PMCMV}^{4}$, ampliando inclusive esta diferenciação residencial. Após seu lançamento em 2009, o programa teve um crescimento exponencial nos anos posteriores, pois as empresas construtoras e incorporadoras, puderam diversificar sua forma de atuação, tornando possível também, a aproximação com o mercado financeiro, graças à abertura de capital na Bolsa de Valores (SHIMBO, 2010; MELAZZO, 2013). Para Fix (2011), o PMCMV reconhece a habitação como princípio do direito assim como o antigo $\mathrm{BNH}$, todavia, paralelamente, esses modelos expressam a moradia como mercadoria. Esse reconhecimento do direito, portanto, tem um caráter ambíguo e contraditório:

Esse reconhecimento do direito tem caráter ambíguo, uma vez que justifica a injeção de recursos públicos em um sistema que, de resto, tem lógica privatista na definição dos espaços, inteiramente formulados segundo os critérios de um empreendimento imobiliário (FIX, 2011, p. 145).

A habitação se caracterizou também por ser um exemplo tácito do projeto neoliberal nas cidades brasileiras, materializando-se através das chamadas políticas de habitação de interesse social, pois prevalece um interesse essencialmente econômico, em que o próprio empreendedor é levado a redefinir áreas de atuação, adequando os financiamentos e atendimento às camadas populares para aumentar o sobrelucro, ou seja, uma clara contradição entre o valor de uso e o valor de troca (FIX, 2011; ROLNIK, 2019).

\footnotetext{
${ }^{4}$ Recentemente foi aprovado o Programa Casa Verde e Amarela, que substitui o PMCMV. O novo programa vem recebendo diversas críticas pois não propõe corrigir os diversos erros do programa anterior como a ausência de infraestrutura nos empreendimentos, construção em regiões distantes do centro (por conta do preço da terra ser menor), a maximização dos ganhos das construtoras em detrimento da habitabilidade, etc. Além disso, o atual programa, mesmo reduzindo taxas de juros para as faixas de renda menor, não tem perspectivas de atender efetivamente essa população, em função da própria crise econômica do país, além de estimular a privatização da regularização fundiária, pois o morador terá a prerrogativa de contratar a regularização para a terra dele e não mais estará sob a responsabilidade do município. https://economia.uol.com.br/noticias/bbc/2020/09/01/casa-verde-e-amarela-versao-bolsonaro-minha-casa-minha-
} vida.htm 
Diante deste quadro, a terra urbana adquire características peculiares, pois ela expressa não só a condição de produção do capital como também a condição de vida da classe trabalhadora. Se por um lado, o processo que garante a propriedade privada segrega a grande maioria da população em função do monopólio da terra (TOPALOV, 1984; HARVEY, 1980; 2016); por outro, mesmo a habitação sendo fundamental para todas as famílias, não consegue atingir plenamente as camadas mais pobres, essencialmente pelo valor. Como a construção da moradia requer um grande investimento de capital e tempo em sua produção e circulação, isso acaba por distanciar o custo do valor do salário de boa parte dos trabalhadores (PINTO, 2004). Para Maricato (2016), a produção residencial na atualidade é uma das novas modalidades do capital financeiro-especulativo:

A mudança de paradigma é que a moradia se transformou em um setor econômico. Passa-se a enxergar a produção residencial como uma das novas fronteiras de expansão do capital financeiro, com um papel de destaque para o crédito hipotecário (MARICATO, 2016, s/p).

Portanto, o processo de produção da moradia tornou-se um fenômeno altamente lucrativo, onde as instituições financeiras, o mercado corporativo e as construtoras formam grandes conglomerados, apoiados muitas vezes pela ação do Estado que dota as terras de equipamentos urbanos e infraestrutura necessária para a reprodução do capital, em áreas privilegiadas e exime-se de condições mínimas de habitabilidade para a população mais pobre. Atesta-se, por exemplo, o questionamento de Negri (2008) sobre o assunto:

Mas por que isso acontece? Acontece porque a maioria dos investimentos públicos é voltada para os bairros da classe de mais alta renda e, como os bairros da classe de baixa renda localizam-se em sua maioria longe do centro e das classes altas, os investimentos públicos acabam chegando - quando chegam - de maneira bastante precária. E isto se reflete nos índices de instrução, de saúde, entre outros (NEGRI, 2008, p. 136).

Desta forma, a atuação do Estado, representado pelas diversas esferas, não se limita à definição urbanística e ao ordenamento da cidade, mas também envolve ajuda às incorporadoras através de concessão de créditos habitacionais, redução de impostos, provimento de infraestrutura e sistemas regulatórios, entre outros mecanismos, ao mesmo tempo, em que promove a restruturação do capital produtivo, ampliando-se novas demandas de consumo e investimentos. Nessa perspectiva, o Estado atua ao lado das corporações, da acumulação capitalista, dando a ideia de uma instituição neutra, a-histórica, acima das classes sociais e dos interesses dominantes (CORRÊA, 2002), ou ainda como um poder coercitivo e regulador, para definir, codificar e dar forma legal ao exercício

\begin{tabular}{lll}
\hline Silva, 2020 & ISSN 0104-5490 & 385
\end{tabular}


supostamente "livre" dos direitos de propriedade privada individualizada, que Harvey (2016) denomina como a primeira linha de contradição entre propriedade privada e Estado capitalista.

\section{ASPECTOS NORTEADORES DO PMCMV}

A partir de 2004, foram criados vários mecanismos financeiros e jurídicos que pudessem atrair a iniciativa privada, salvaguardando os seus interesses e dando margem de lucro ${ }^{5}$. Na mesma linha adotada pelo governo, houve o aumento de recursos destinados ao financiamento habitacional e incentivos fiscais, estabelecendo subsídios para a criação do Programa Minha Casa Minha Vida (PMCMV) anos depois.

Gestado em março de 2009 através da 11.977/2009, este programa foi fruto de uma intervenção estatal, juntamente com a iniciativa privada, a fim de "deter" a forte crise econômica que tinha assolado os principais países capitalistas do mundo em 2008, após a desestruturação financeira e imobiliária nos EUA. Assim, o principal objetivo desta intervenção era a reestruturação do mercado habitacional e tentar conter a crise no âmbito nacional (BONDUKI, 2009). O programa baseou-se em dois pilares fundamentais: estimular o desenvolvimento do setor da construção civil e o crescimento de emprego e da economia do país, este último pilar, favorecido essencialmente pelo consumo da população.

Em função das mudanças político-econômicas e pela segurança jurídica do programa, a atração não se deu apenas a grandes imobiliárias e incorporadoras, mas também de pequenas e médias que não estavam associadas às grandes movimentações financeiras. Destaca-se a forte participação de algumas empresas do setor imobiliário em operações na Bolsa de Valores, cujos recursos são utilizados para ampliar suas atividades, investindo em terras ou em novos empreendimentos e no desenvolvimento da financeirização do setor no país (MELAZZO, 2013; SANFELICI, 2015; ROLNIK, 2019).

O PMCMV define atualmente que há quatro grupos de famílias que podem ter acesso à moradia. O faixa 1 destinado a famílias com renda de até $\mathrm{R} \$ 1.800,00$, faixa 1,5 para famílias com renda de até $\mathrm{R} \$ 2.600,00$, faixa 2 com renda de até 4.000,00 e faixa 3 com renda que não podem ultrapassar R $\$ 7.000,00$. Na faixa 1, objeto de nossa análise, a prefeitura faz o cadastro das famílias,

\footnotetext{
${ }^{5}$ Shimbo (2010) destaca que através do $\mathrm{PNH}$, o governo adotou algumas medidas importantes: a primeira foi a de promover a segurança jurídica e econômica ao mercado privado em 2004, cujos intuitos eram o combate à inadimplência dos mutuários e a livre atuação dos capitais de origem imobiliária; a segunda foi a criação de novos títulos de crédito e a ampliação de recursos financeiros ao mercado privado.
} 
utilizando critérios tanto locais, como a análise dos aspectos socioeconômicos e das condições de vulnerabilidade social e precariedade habitacional das famílias e, critérios nacionais como famílias residentes ou que tenham sido desabrigadas de áreas de risco ou insalubres, famílias que façam parte Pessoa com Deficiência (PcD) e famílias com mulheres responsáveis pela unidade familiar. Em seguida, as famílias selecionadas pela prefeitura são analisadas pela Caixa, cujos critérios são a renda compatível com a modalidade (até 1.800,00), não ser proprietário, cessionário ou promitente comprador de imóvel residencial e não ter recebido benefício de natureza habitacional oriundos de recursos municipais, estaduais e da União. Por fim, as famílias selecionadas pelas prefeituras e validadas pela Caixa, são comunicadas sobre a data do sorteio das unidades e da assinatura do contrato de compra e venda do imóvel (BRASIL, s/d).

Foi estabelecida ainda, uma tipologia mínima para casas térreas $\left(35 \mathrm{~m}^{2}\right)$ e apartamentos $(42$ $\mathrm{m}^{2}$ ) do programa, nos quais devem possuir: 02 quartos, sala, cozinha, banheiro, área de serviço para apartamentos e área externa com tanque para casas. São definidas também, as especificidades técnicas, hidráulicas e elétricas do empreendimento (BRASIL, s/d).

O Distrito Federal, Estados e Municípios ou órgãos que aderirem ao Programa tem efetivação através do termo de adesão com a Caixa e colaboram na implementação dos projetos, definindo áreas priorizadas para execução, na isenção de tributos, no aporte de recursos, na indicação de demandas e de solicitantes para a venda dos empreendimentos e, na execução do trabalho técnico social junto aos beneficiários. Empresas da construção civil que apresentam projetos e tendo sua aprovação efetivada, executa-os na forma estabelecida pelo Programa, além de guardar os imóveis prontos e legalizados pelo prazo de 60 dias (BRASIL, s/d).

\section{A INSERÇÃo do PMCMV NA CIDAdE de MOSSORÓ E A CARACTERIZAÇÃo SOCIOESPACIAL DO CONJUNTO SANTA JÚLIA}

Com novas demandas de consumo, diversas ações materializam-se também em várias cidades médias brasileiras, através da multiescalaridade dos fenômenos e pelas interações espaciais (CORRÊA, 2007), possuindo dinâmica econômica e demográfica próprias, atendendo expectativas de empreendedores e cidadãos (MOTTA e MATA, 2008). Por outro lado, a inserção destas cidades, enquadra-se num contexto de capitalismo pós-fordista e flexível, com repercussões efetivas nos serviços, no lazer e nos negócios, restritas antes, principalmente nos séculos XIX e XX, às metrópoles e grandes cidades (SPOSITO, 2006), reafirmando, portanto, o papel de polo, de funções e importância 
de comando frente a outras cidades, como bem demonstrado em estudos recentes (IBGE, 2008; 2019), em meio ao desenvolvimento e expansão do fenômeno da globalização (SILVEIRA, 2002; DAMIANI, 2006).

No campo habitacional, têm surgido estudos importantes sob a ótica hegemônica do capital como a análise das construtoras, do sistema financeiro, das imobiliárias e dos mercados de terras, seja na produção das cidades médias e nos respectivos efeitos socioespaciais (VIEIRA, 2009; ABREU, 2016; AMORIM, 2017), especialmente com a profusão do PMCMV (MELAZZO, 2015).

É neste contexto de mudanças significativas que se enquadra a cidade de Mossoró. Situa-se no oeste do estado do Rio Grande do Norte no nordeste brasileiro e de acordo com o censo de 2010, do Instituto Brasileiro de Geografia e Estatística (IBGE) sua população era estimada em 259.815 mil habitantes, tendo 237.241 habitantes vivendo em sua área urbana, numa densidade demográfica de 123,76 hab. $/ \mathrm{km}^{2}$. Em 2020, a população estimada eleva-se para 300.618 habitantes (IBGE/CIDADES, 2020).

As atividades econômicas se caracterizaram como fatores importantes para o desenvolvimento e a atual conformação da cidade. Ao final do século XIX e início século XX, por exemplo, as atividades salineiras e de oleaginosas, como o algodão e a carnaúba, consolidaram o crescimento populacional e a formação de um centro regional por conta da sua produção e comercialização ${ }^{6}$, garantindo a instalação de indústrias e das agroindústrias para a intensificação do desenvolvimento agrícola no local e, fortalecendo o papel da cidade como centro distribuidor e sede industrial (ROCHA, 2005).

Anos seguintes, a cidade recebeu forte investimento estatal através da Superintendência de Desenvolvimento do Nordeste (SUDENE) e do Polo de Desenvolvimento Integrado Açu-Mossoró na fruticultura irrigada ${ }^{7}$, especialmente na década de 1970. Entre as décadas de 1980 e 1990, há o impulsionamento de novas atividades econômicas como o petróleo ${ }^{8}$ e a reestruturação das já existente

\footnotetext{
${ }^{6}$ Esta expansão é consolidada e amparada pelo acesso à terra cada vez mais restritivo no país, com a Lei de Morgadio de 1835 que institucionalizava a sucessão de terras e a manutenção do latifúndio e, a Lei de Terras de 1850, cujas terras devolutas passavam a ser do Estado e, sua apropriação, dava-se apenas através da compra e venda, estimulando, portanto, a tradição latifundiária brasileira (CAVALCANTE, 2005).

${ }^{7}$ Forte produção do agronegócio, através da agricultura irrigada, destacando-se o polo fruticultor Açu-Mossoró, com a produção de melão, abacaxi, melancia, castanha de caju e mamão. Todavia, é uma atividade altamente concentradora de terras e beneficiamento de produtores rurais capitalizados de médio e grande portes.

${ }^{8}$ A exploração de petróleo (1980-1990) pela Petrobras, notadamente conhecida com uma das mais importantes explorações por terra do país, impulsionou a instalação de uma série de empresas que dão suporte à atividade: perfuração de poços, fornecimento de mão de obra, manutenção industrial e locação de equipamentos, mão de obra especializada em petróleo e gás, serviços de manutenção, instalação, montagem e operação de equipamentos (DOMINGUES, 2014). 
como o $\mathrm{sal}^{9}$, com a mecanização da exploração, dinamizando assim, outros setores da economia local (SOARES, 2015). Houve ainda, forte diversificação das atividades econômicas, destacando-se comércio e serviços nos últimos anos e o crescimento do PIB municipal pela instalação de indústrias.

A valorização imobiliária e fundiária de novas zonas da cidade tem definido áreas de ocupação habitacional, de comércio e novas centralidades, com ampla participação do governo local, condicionando um padrão de expansão seletiva. Em meados dos anos 2000, a zona oeste da cidade por exemplo, recebeu diversas intervenções, como o prolongamento de avenidas (ligando o centro da cidade), a dotação de infraestrutura, equipamentos urbanos e a doação do terreno pela prefeitura para instalação do shopping Partage em 2007, acentuando, portanto, a atração de escolas, faculdades privadas, comércio e condomínios fechados como o Alphaville Mossoró em 2008, resultando ainda, no aumento do preço da terra, intensificação da especulação imobiliária e moradia de pessoas com maior rendimento, nesta parte da cidade (COUTO, 2017).

A participação do poder público com o potencial gerado pelas atividades econômicas no município, tem impulsionado o mercado imobiliário, com a atração de capitais regionais e nacionais, todavia, ampliam-se a auto-segregação, através dos condomínios fechados para os setores com maiores rendimentos e a instalação dos loteamentos e habitações, para as classes populares com o processo de periferização, ou seja, áreas distantes do centro, com reduzida infraestrutura e mobilidade, atendendo aos interesses imobiliários e fundiários, em detrimento da habitabilidade da população, com a profusão do $\mathrm{PMCMV}^{10}$ (NASCIMENTO, 2014).

Neste contexto, o PMCMV tem operado desde 2010 na cidade de Mossoró e os dados mostram o volume de contratações até março de 2018, ou seja, 3.646 unidades do faixa 1 (BRASIL, 2020). Ao relacionarmos o déficit habitacional total em 2015, ou seja, 10.563 moradias (FJP, 2017) com o número de contratações do Programa Minha Casa Minha Vida até 2016, ano da última contratação (CEF, 2020), constata-se, que o número de unidades representou $34 \%$ do déficit total. A título

\footnotetext{
${ }^{9}$ O Rio Grande do Norte produz aproximadamente de $90 \%$ da produção brasileira, com forte participação de Mossoró. Na produção e comercialização destacam-se as de capital estrangeiro (BEZERRA et al., 2012).

${ }^{10} \mathrm{Em}$ várias cidades médias, o impacto das políticas públicas de habitação foi fundamentalmente muito maior, se compararmos com muitas capitais brasileiras, no que concerne à provisão de moradias, ou seja, quando relacionamos o déficit habitacional total em 2015 (FJP, 2017) com o número de contratações do Programa Minha Casa Minha Vida até 2018 (BRASIL, 2019) temos tal percepção. Em Ituiutaba-MG por exemplo, a quantidade de moradias produzidas até 2015, foi superior ao número total do déficit habitacional, atingindo mais de 100\%. Em Dourados-MS atingiu $65 \%$, em Presidente Prudente-SP 60\% e, em Marabá-PA 37\% do déficit. A título comparativo com capitais, onde o déficit costuma ser bem maior, Natal-RN, contratou 2.888 unidades contratadas, com um déficit em 2015 de 40.000 moradias, em VitóriaES foram contratadas 128 unidades habitacionais para um déficit de 6.345 moradias e, em Recife-PE, apenas 1.008 unidades contratadas, para um déficit de 94.964 moradias para o ano de 2015 , representando, portanto, $7 \%$, 2\% e $1 \%$ respectivamente.
} 
ilustrativo, são demonstrados os anos e o número de unidades habitacionais ${ }^{11}$ que ocorreram contratações pelo programa, na modalidade faixa 1 (Figura 01), especialmente nos anos de 2010 e 2013, onde verificam-se os maiores índices registrados, impulsionadas pela conjuntura econômica brasileira:

Figura 01: Unidades contratadas por ano

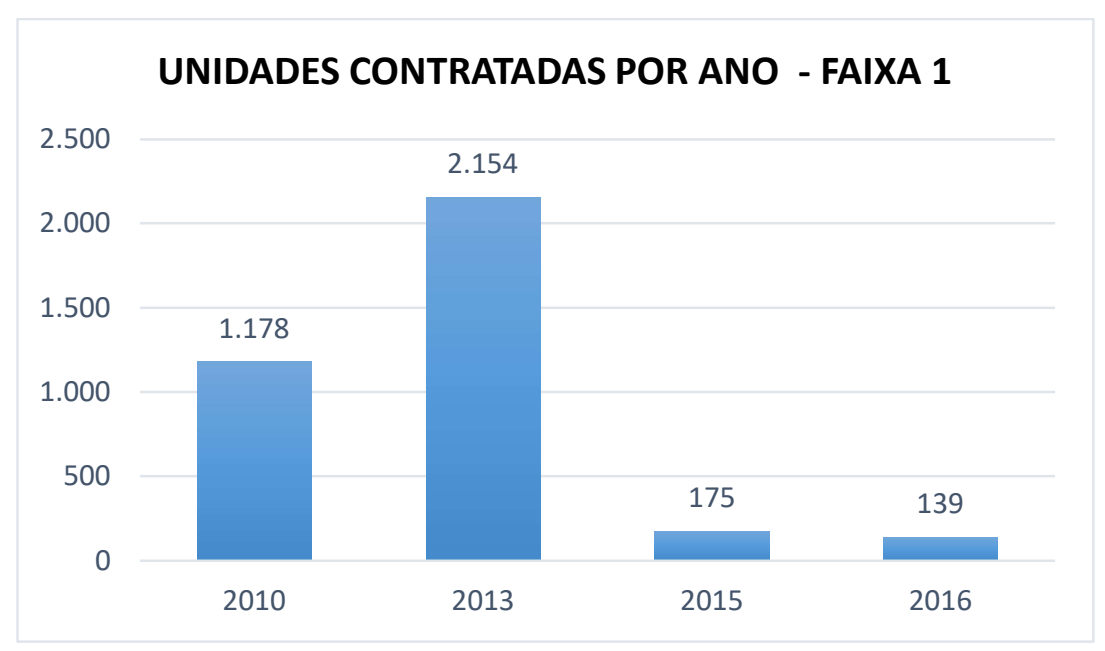

Fonte: BRASIL, 2019.

Em geral, a distribuição espacial dos empreendimentos desta modalidade, segue uma tendência nacional, onde ocorre a intensificação da periferização nas cidades e a carência das necessidades básicas para a população mais pobre que habita, ampliando o processo de segregação e desigualdade socioespacial das famílias que são atendidas pelo programa nesta modalidade (CARDOSO; ARAGÃO, 2013; ROLNIK, 2019; SOUZA; LEITE, 2019). Em Mossoró, analisou-se empiricamente o Residencial Santa Júlia (Figura 02), no bairro Abolição V com 376 unidades, cuja contratação ocorreu em 2010 e foi entregue no segundo semestre de 2015.

Figura 02: Localização do Residencial Santa Júlia

\footnotetext{
${ }^{11}$ Exclui-se deste levantamento contratos cancelados e distratados pela Caixa Econômica Federal, além dos anos em que não houve contratações oficiais.

Silva, $2020 \quad$ ISSN 0104-5490 


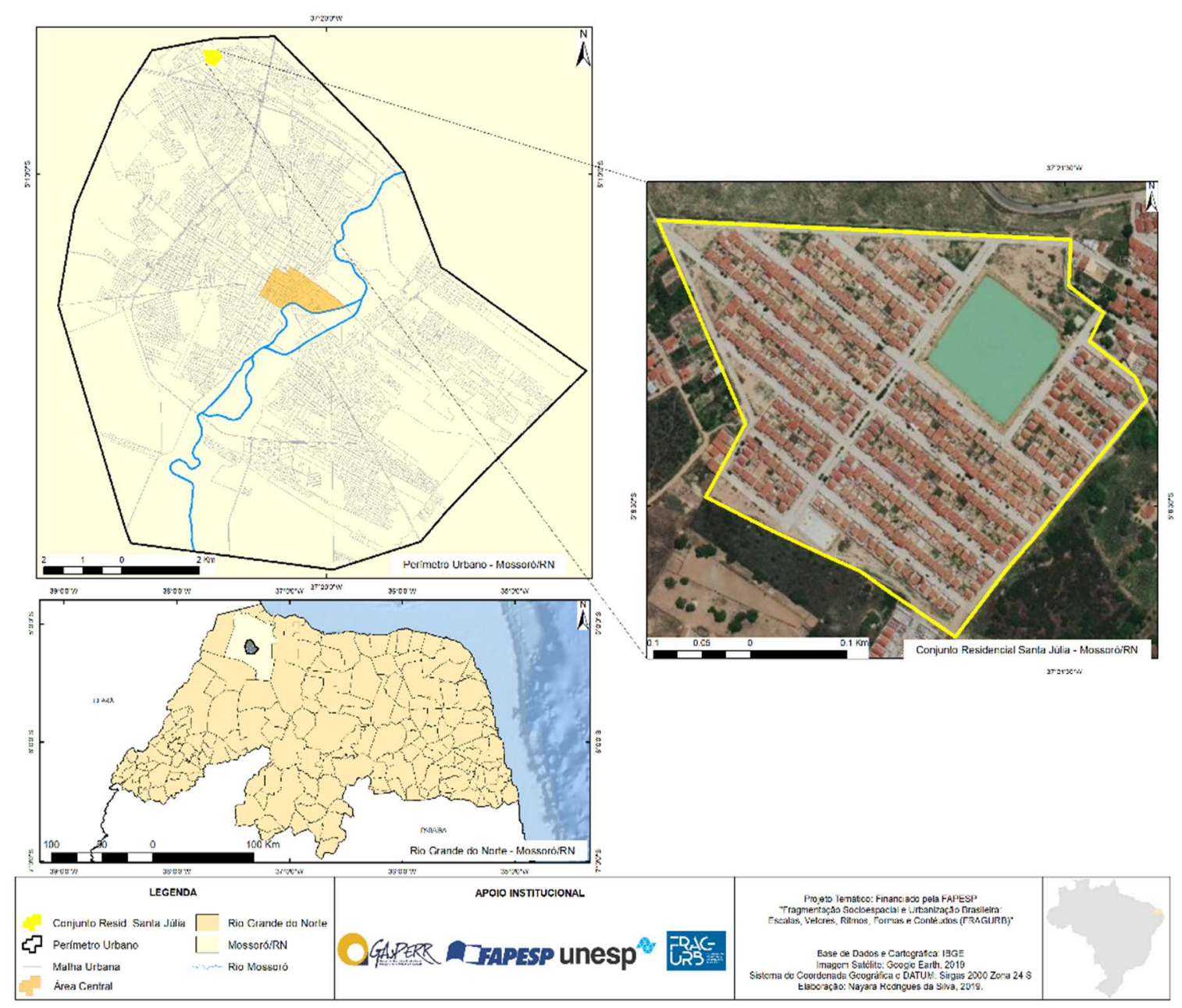

Fonte: Base Cartográfica: Instituto Brasileiro de Geografia - IBGE, 2019; Sistema de Coordenadas Geográficas. Datum SIRGAS, 2000.

Através do trabalho de campo e da aplicação de 40 questionários de múltipla escolha, para membros familiares que compõem as unidades do residencial, essencialmente beneficiárias, foi traçado o perfil socioeconômico dos moradores, a percepção dos habitantes sobre o lazer no residencial, formas de deslocamento no espaço intra-urbano, bairros de origem das famílias, serviços públicos e elementos de organização dos moradores, como associações.

No que concerne ao ano de chegada no residencial dos moradores, $67 \%$ responderam que estão desde 2015, ou seja, ano de entrega do empreendimento, enquanto $17 \%$ chegaram em 2016, 10\% em 2017 e, nos anos de 2018 e 2019, cerca de 3\%. Salienta-se que os períodos que sucedem a 2016 coincidem com outros padrões de aquisição da moradia, enquanto os dois primeiros períodos, as famílias passaram por um processo de cadastro e seleção pela prefeitura, os anos subsequentes coincidem com outras modalidades de aquisição, como aluguel e repasse, com aproximadamente 16\% dos entrevistados. 
Apesar do número pequeno e tal modalidade ser proibitiva pelo programa, muitos alegam a não adaptabilidade de algumas famílias para o local, especialmente quando se trata da ausência de equipamentos urbanos e distância do comércio, trabalho, casas de parentes, entre outros, cujas estruturas (mobiliário urbano, por exemplo), as famílias possuíam na moradia anterior, mesmo que em algumas situações limitadas ou precariamente. Para exemplificar, evidencia-se a distância do residencial ao centro da cidade, ou seja, aproximadamente $7 \mathrm{~km}$, num local onde as condições do transporte público são precárias e o preço das passagens é elevado, para o padrão de consumo das pessoas que lá habitam. Isso vem interferindo, na permanência das famílias no residencial, ao passo que algumas delas voltam para o bairro de origem, como o bairro Santo Antônio, nas proximidades do centro da cidade (cerca de 1,5 km), de onde muitas pessoas vieram, mesmo pagando aluguel ou morando na casa de parentes.

Bonduki (2009) já tinha demonstrado preocupação e possíveis consequências quanto ao fator localização do programa:

A localização dos empreendimentos poderá ser inadequada, em áreas carentes de emprego, infraestrutura e equipamentos, correndo o risco, ainda, de gerar impactos negativos como a elevação do preço da terra, que representaria a transferência do subsídio para a especulação imobiliária, desvirtuando os propósitos do programa (BONDUKI, 2009, n.p).

A título ilustrativo, meses após a conclusão e ocupação do empreendimento e, até completado um ano de entrega das casas, os moradores questionavam a ausência de equipamentos e estruturas básicas para a habitabilidade no local, como demostra uma enquete em rede social, feita pelos próprios moradores acerca das impressões que eles tinham sobre o residencial (Figuras 03 e 04):

Figuras 03 e 04: Depoimento de moradores em enquete de rede social, nos anos de 2016 e 2017

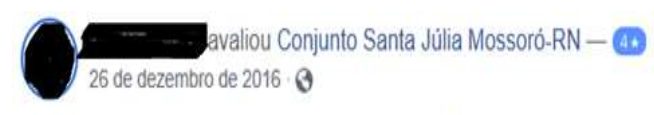

Muito tranquilo tem boa iluminaçăo só o que năo temos é um transporte escolar, um posto de saúde, praça pra poder as crianças terem um lazer perto de casa, eu amo minha moradia è um sonho que esperei 6 anos

(1) 9

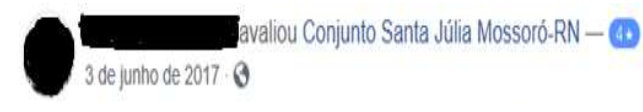

Um conjunto aparentemente tranquilo mas ainda sem as estruturas básicas para a população dali. Faltam escolas postos de saúde conduçăo mais por ser um conjunto novo, talvez venha a ter todos esses recursos um dia. No mais dar pra morar.

01

Fonte: Facebook, 2019.

O grau de instrução (Figura 05) dos entrevistados revela ainda, o baixo nível de escolaridade dos moradores, com grande parcela da população que não concluiu tanto o ensino fundamental quanto o ensino médio escolar, isso tem repercutido fortemente também no alto índice de desemprego e

\begin{tabular}{lll}
\hline Silva, 2020 & ISSN 0104-5490 & 392
\end{tabular}


subemprego. Cerca de $27 \%$ dos moradores analisados, alegam possuir emprego com carteira assinada e outros 5\% intitularam-se aposentados que recebem benefício, todavia, $22 \%$ dizem-se desempregados e, $45 \%$ realizam trabalhos informais, sem vínculo empregatício efetivo. São os mais variados modos possíveis de subempregos, como ajudante de pedreiros, vendedoras de doces e salgados, pintores, administração de pequeno comércio na residência, entre outras ocupações que variam ao longo do ano, em função da disponibilidade de serviços, como os trabalhos temporários no final de cada ano.

Figura 05: Grau de instrução dos moradores

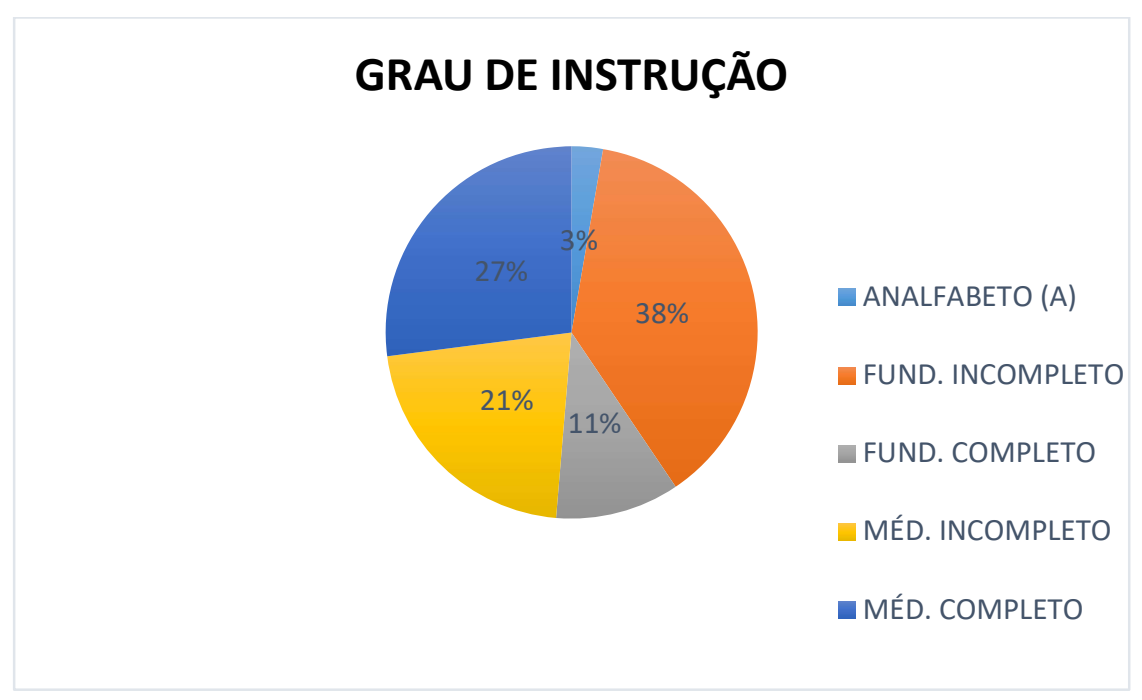

Fonte: Trabalho de campo, 2019.

Há paralelamente, um forte impacto na baixa renda familiar, em função da não empregabilidade ou do subemprego/precarização da população nacional (ANTUNES, 2018; POCHMANN, 2018), que também se reflete no quadro local (Figura 6). Basta verificar os dados para compreender que a média mensal de ganhos da família, gira em torno de um salário mínimo, muitas vezes com um único membro empregado (cujas famílias são essencialmente numerosas), ocupado profissionalmente ou recebendo algum tipo de benefício como aposentadoria.

Isto tem impactado consideravelmente no consumo e nas despesas mensais da família como energia, alimentação e transporte. Salienta-se ainda, que para algumas pessoas há uma margem de variação dos ganhos ao longo dos meses, em função da própria natureza da ocupação ${ }^{12}$, uma vez que

\footnotetext{
${ }^{12}$ Há uma variação de ganhos mensais, exatamente pela disponibilidade ou não de serviços ou ainda pela própria demanda como a venda de bolos e doces, a contratação do pedreiro para determinadas reformas e reparos, dos serviços de manicure para os moradores etc.
} 
parcela significativa dos moradores declara não possuir trabalho fixo, são os chamados subproletários $^{13}$ (SINGER, 2009).

Muitos integrantes vivem com os ganhos do trabalho temporário, informal ou mesmo de "bicos", estando inseridos também em programas de transferência de renda que complementam os ganhos, como alegam $42 \%$ dos entrevistados, como bolsa família e bolsa escola, por exemplo. Instrumentos importantes que funcionam assim, como mecanismos que podem ajudar no acréscimo dos poucos recursos familiares mensais.

Figura 6: Renda familiar

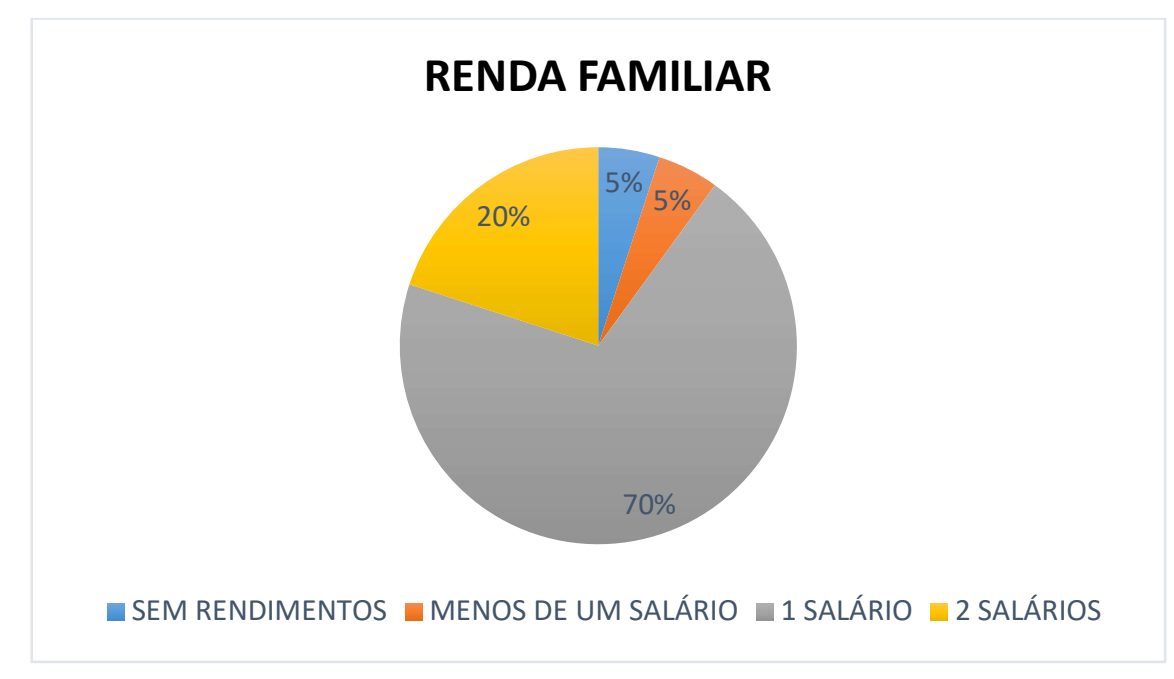

Fonte: Trabalho de campo, 2019.

Ao mesmo tempo, se constata um grande quantitativo de integrantes familiares por moradia (Figura 7). Logo, a casa termina acomodando assim, no geral, entre três (30\%) e quatro (35\%) pessoas, às vezes até mais, como demostra o gráfico a seguir. São os mais variados membros como pais, filhos, avós, tios e sobrinhos, todavia, é importante salientar, que a tipologia das casas é padronizada no programa, com cerca de $32 \mathrm{~m}^{2}$, ou seja, fundamentalmente pequenas para comportar famílias com muitos integrantes.

Figura 7: Integrantes familiares por moradia

\footnotetext{
${ }^{13}$ SINGER (2009) denomina de subproletários os trabalhadores amparados pela desproletarização do trabalho industrial, falta de organização política e o aumento dos serviços mal remunerados e precarizados. Inserindo os que possuem renda de até um salário mínimo per capta, por exemplo. 


\section{INTEGRANTES FAMILIARES POR MORADIA}

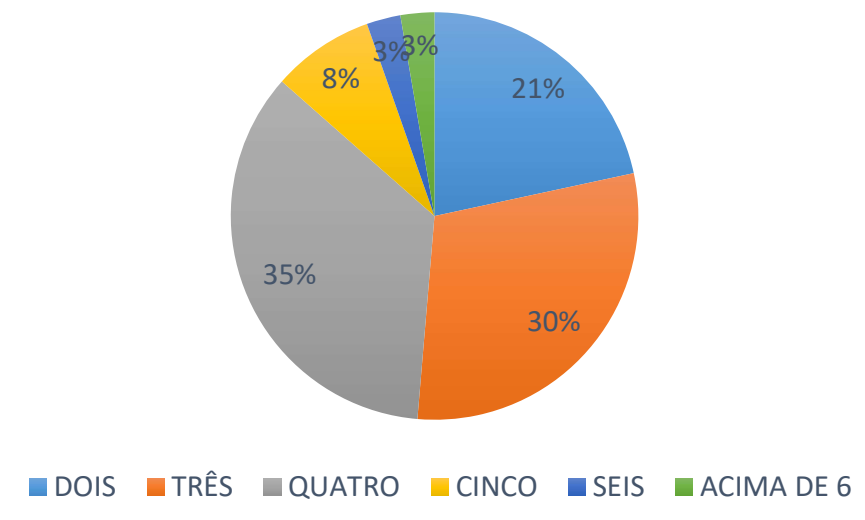

Fonte: Trabalho de campo, 2019.

Os moradores questionam ainda, os próprios materiais utilizados tanto na estrutura quanto no acabamento, essencialmente pela qualidade do material empregado na obra, deteriorando-se rapidamente. Este foi um tema abordado por Cardoso e Aragão (2013), onde foi questionado o poder das construtoras sobre a promoção imobiliária, ou seja, a tendência era que por estarem trabalhando com valores pré-estabelecidos, como limites para o preço final dos seus produtos, as grandes construtoras reduziriam seus custos, com ganhos na produtividade e que não seriam repassados aos compradores, na qualidade dos produtos oferecidos.

Como forma de minimizar o tamanho das moradias, garantir privacidade e segurança e, ainda, melhorar a habitabilidade, muitas famílias optam em construir novos vãos, alargar parte da casa, erguer muros ou alterar estruturas. Esta última modalidade, especialmente para famílias que possuem maior renda, ao passo que a grande maioria termina se endividando na compra de materiais de construção e na contratação de profisssionais para as devidas reformas necessárias.

O residencial possui apenas uma área de lazer, uma quadra descoberta que atende basicamente crianças e jovens e ocasionalmente acontece uma atividade recreativa para as famílias, como datas comemorativas. Assim como é evidente ainda, a ausência de parques, praças e locais para manifestações culturais, prática de esportes, sob as mais diferentes modalidades e o convívio entre os moradores $^{14}$. Não há Unidade Básicas de Saúde (UBS) no residencial e a construção do prédio da

\footnotetext{
${ }^{14}$ A portaria $\mathrm{N}^{\circ} 168$, de 12 de ABRIL de 2013, dispõe que o empreendimento deverá ser dotado de infraestrutura básica, ou seja, equipamentos sociais e serviços, incluindo espaço coberto para uso comunitário, unidades adaptadas para as famílias das quais façam parte pessoas com deficiência, saneamento e energia elétrica, entre outros itens. Ver em: https://central3.to.gov.br/arquivo/405543/
} 
unidade que funcionará no bairro, está com atraso e sem previsão de entrega aos moradores do Santa Júlia (Figura 8).

Figura 8: Unidade Básica de Saúde (UBS) em construção

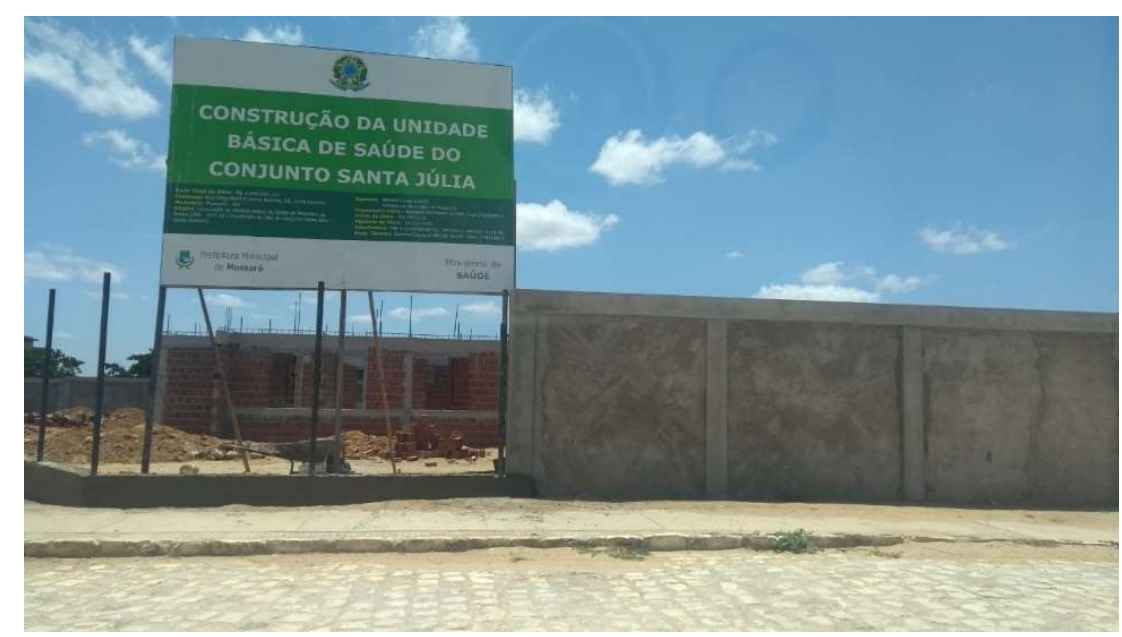

Fonte: Cláudio Smalley, 2019.

Muitos moradores precisam se deslocar para outras unidades de bairros vizinhos, como as UBS Dr. Ecolástico Bezerra (Santa Delmira) e Dr. Moisés da Costa Lopes (Redenção) para serem atendidos, todavia, há um sobrecarrego nestas unidades, exatamente pelo atendimento da população além de sua abrangência territorial, comprometendo a qualidade do serviço e a disponibilidade de vagas para procedimentos simples, como exames por exemplo (Figura 9). No que concerne a escolas, as mais próximas do residencial são as do bairro Redenção, isto é, as escolas Estaduais Luiz Dantas Cavalcanti, Diran Ramos do Amaral e a escola Municipal Alcides Manoel de Medeiros. 
Figura 9: Mapeamento de localização e distância dos principais equipamentos públicos

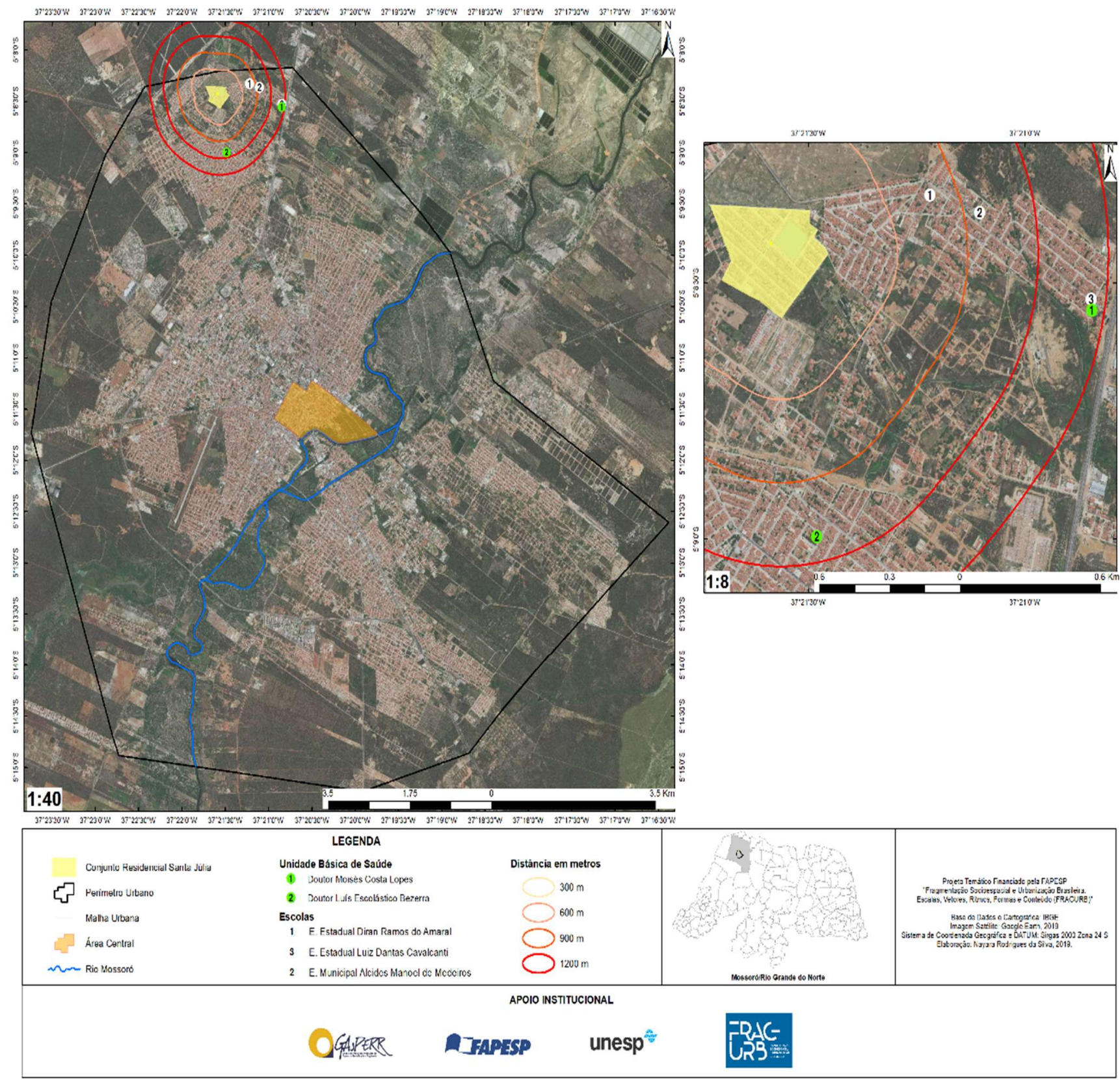

Fonte: Base Cartográfica: Instituto Brasileiro de Geografia - IBGE, 2019; Sistema de Coordenadas Geográficas. Datum SIRGAS, 2000

É de destacar ainda, a dificuldade de deslocamento da população do Santa Júlia (Figura 10), no que se refere ao transporte público, o tempo de espera entre os intervalos dos ônibus pode chegar a uma hora, como relataram muitos dos entrevistados. Também não há transporte que circula no residencial, apenas no bairro vizinho, cujo deslocamento é realizado a pé para a via de circulação do ônibus. Há o comprometimento dos ganhos das famílias ainda, pelo valor da passagem do transporte 
público na cidade, para o deslocamento até o centro por exemplo, ao custo de $\mathrm{R} \$ 3,30$. A própria qualidade do serviço oferecido é considerada pelas famílias como ineficaz, pela frota reduzida dos ônibus para atender o bairro durante a semana e, nos fins de semana, quase inexistente. Resta a opção para muitas pessoas, do deslocamento através dos transportes alternativos e aplicativos como Uber, mototáxis ou mesmo táxis, realizados por cerca de 16\% dos entrevistados; o descolamento a pé, respondidos por $24 \%$ e, a circulação através de motos e carros próprios com $38 \%$ dos entrevistados. O comprometimento da renda mensal familiar, em raros momentos de circulação, através do transporte de caráter privado, revela a problemática do transporte público na cidade.

Figura 10: Formas de deslocamento dos moradores

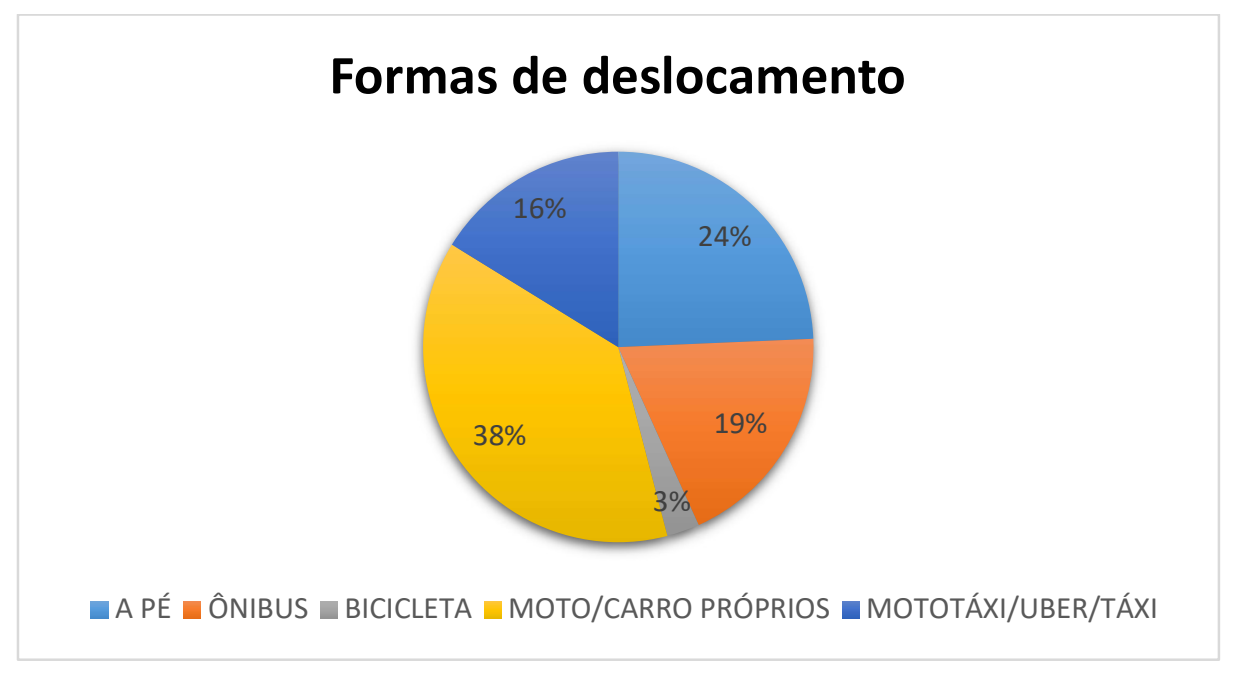

Fonte: Trabalho de campo, 2019.

Atrela-se ainda, a flexibilidade e o parcelamento da compra de motos de baixa cilindrada, algo muito comum no município, como mecanismo importante para o deslocamento da população para o trabalho e estudos, para realização de "bicos" ou serviços temporários ou para fazer compras, visitar parentes etc. Portanto, há um forte impacto na renda pelo uso de transporte alternativo, ao passo que o deslocamento realizado a pé pelos moradores é muito comum, em função da impossibilidade de utilização dos transportes oferecidos, especialmente quando se trata da ida ao médico e escola. A mobilidade da população de baixa renda na periferia, portanto, apresenta vários problemas de deslocamentos cotidianos, fundamentalmente se comparados a estratos de renda mais alta (VASCONCELOS, 2001).

Quanto à percepção no que se refere a existência da associação de moradores, 62\% desconhecem que esteja ativa, o restante, ou seja, 38\% reconhecem que existe a entidade, todavia, 
relatam que há pouca atuação das lideranças ou mesmo ausências de encontros regulares para debater assuntos e problemas evidenciados pelos moradores, nas chamadas reuniões ou assembleias. Observa-se que há um processo de relação clientelista entre algumas lideranças do conjunto analisado para com os governantes locais ou políticos das mais diferentes esferas, que atuam na cidade. A conquista de determinadas ações no residencial, reflete muito mais uma ação individual da liderança junto ao político, acompanhado muitas vezes com a possibilidade de votos nas futuras eleições, do que uma ação coletiva, educativa e de resistência dos moradores, configurando no que ficou denominado por Souza (2006) como ativismo paroquial. Neste sentido, ocorre um processo de cooptação e permanência de relações clientelistas e corporativas, tendo um rebatimento, portanto, nas condições estruturais do conjunto.

\section{CONCLUSÕES}

Foi possível observar neste estudo o padrão de expansão seletivo no município, com a reprodução de espaços segmentados, ampliando o processo de periferização, para a população mais pobre (especialmente com a chegada do PMCMV), que passou a impactar na provisão habitacional em cidades médias brasileiras, como na cidade de Mossoró. Esta mesma população possui um perfil socioesconômico com baixa escolaridade, altos índices de desemprego e subemprego, interferindo decisivamente no cotidiano e nas condições de vida das famílias. Evidenciou-se ainda, serviços públicos e equipamentos sociais insuficientes, distantes da população do conjunto residencial, ao passo que a tipologia das habitações potencializa a construção de casas diminutas e com material de qualidade inferior. Por outro lado, há um sistema de transporte deficiente e um comprometimento efetivo da renda familiar com os deslocamentos, através dos chamados transportes alternativos.

É decisiva ainda, a participação e o papel do governo local, no direcionamento e expansão da cidade, na concessão de áreas para o segmento construtivo, na dotação de vias, equipamentos urbanos e obras de saneamento. Todavia, esta dotação atende, fundamentalmente, a iniciativa privada através da construção de novos empreendimentos comerciais, residenciais de alto padrão, em detrimento das áreas onde se encontram as famílias pobres. Como mecanismo de exemplificação citam-se a ausência de praças, parques, escolas e postos de saúde no próprio residencial, configurando, portanto, a intensificação da fragmentação socioespacial.

No quesito organização dos moradores e mecanismos de reivindicação, observa-se a inexistência de elementos de contraposição e cooperação, para a luta das famílias na conquista de melhorias para o residencial. Há, essencialmente, uma ação de cooperação e clientelismo das 
"lideranças" do conjunto para com o poder local, na tentativa de conquistas e necessidades básicas das famílias, ampliando a falta de protagonismo dos moradores e o caráter meramente formal da associação que opera no lugar.

Portanto, diante deste contexto, o Conjunto Residencial Santa Júlia reflete o processo de fragmentação do PMCMV, o caráter seletivo de distribuição da população mais pobre no espaço, ampliada pela ação do poder público local e, o grau de precariedade no oferecimento de equipamentos públicos, além da inexistência de ações reivindicativas eficazes em contraposição a este modelo. $\mathrm{O}$ Programa Casa Verde e Amarela, lançado pelo Governo Federal em agosto de 2020, parece não tencionar no sentido de resolução dos problemas evidenciados neste texto, verificados no PMCMV, todavia, é preciso avançar nas análises e nas discussões da concepção do novo programa e no rebatimento na população pobre do país. Pois, a reorientação de políticas públicas habitacionais para os segmentos mais carentes da população, precisa levar em consideração as contradições deste modelo implementado ao longo dos anos e a repercussão na habitabilidade cotidiana das famílias, especialmente quando se leva em consideração um bem essencial que é a habitação.

\section{REFERÊNCIAS}

ABREU, Marlon Altavini. Diferenciando o espaço e produzindo cidades: lógicas e agentes da produção do espaço urbano nas cidades de Ribeirão Preto/SP e Londrina/PR. GeoTextos, vol. 12, n. 1, julho 2016. p. 77-104.

ANTUNES, Ricardo. O privilégio da servidão. São Paulo: Boitempo, 2018.

AMORIM, Wagner Vinicius. A produção imobiliária e a reestruturação das cidades médias: Londrina e Maringá (PR). São Paulo: Cultura Acadêmica, 2017.

ASSOCIAÇÃO BRASILEIRA DE NORMAS TÉCNICAS. Cartilha do MCMV. Programa Minha Casa Minha Vida. 2008. Disponível em: http://www.ademi.org.br/docs/CartilhaCaixa.pdf. Acesso em: 04 nov. 2019.

BONDUKI, N. G. Do Projeto Moradia ao Programa Minha Casa Minha Vida. TD. Teoria e Debate, v. 82, p. 1, 2009.

BEZERRA, J. M; BATISTA, R. O; SIlVA, P. C. M. da; MORAIS, C. T. S. L; FEITOSA, A. P. Aspectos econômicos e ambientais da exploração salineira no estado do Rio Grande do Norte. Engenharia Ambiental - Espírito Santo do Pinhal, v. 9, n. 2, p. 003-020, maio/jun. 2012. 
BRASIL. Caixa Econômica Federal. Programa Minha Casa Minha Vida. Brasília, s/d. Disponível em: http://www.caixa.gov.br/voce/habitacao/minha-casa-minha-vida/urbana/Paginas/default.aspx. Acesso: 04 ago. 2020.

BRASIL. Ministério do Desenvolvimento Regional. Sistema de Habitação (SISHAB). 2019. Disponível em: http://sishab.cidades.gov.br/empreendimentos/filtro. Acesso: 04 ago. 2020.

CARDOSO, A.; ARAGÃO, T. Do fim do BNH ao Programa Minha Casa Minha Vida: 25 anos da política habitacional no Brasil. In: CARDOSO, A. (Org.). O programa Minha Casa Minha Vida e seus efeitos territoriais. Rio de Janeiro: IPPUR/Letra Capital, 2013.

CASTRO, Carla Yara Soares de Figueirêdo. O corredor cultural: espaço de materialização da exclusão social em Mossoró-RN. Tese (Doutorado em Ciências Sociais) - Universidade Federal do Rio Grande do Norte. Centro de Ciências Humanas, Letras e Artes. Programa de Pós-Graduação em Ciências Sociais, Natal, 2012. 172 p.

CAVAlCANTE, José Luiz. A Lei de Terras de 1850: e a reafirmação do poder básico do Estado sobre a terra. Edição $\mathrm{n}^{\mathrm{o}} 2$ de junho de 2005. Disponível em: http://www.historica.arquivoestado.sp.gov.br/materias/anteriores/edicao02/materia02/LeideTerra.pd f. Acesso: 01 fev. 2020.

CORRÊA, R.L. Região e organização espacial. $7^{\mathrm{a}}$ edição. São Paulo: Ática, 2002.

. Construindo o conceito de cidades médias. In: SPOSITO, M. E. B. (Org.) Cidades médias: espaços em transição. $1^{\mathrm{a}}$ edição, São Paulo: Expressão Popular, 2007, p.23-33.

COUTO, Edna Maria Jucá. As cidades médias e suas múltiplas particularidades: produção e consumo do espaço urbano em Marília-SP e Mossoró-RN. Tese (Doutorado em Geografia) Universidade Estadual de São Paulo. Programa de Pós-Graduação em Geografia, Presidente Prudente, 2016. p.

DAMIANI, Amélia Luisa. Cidades médias e pequenas no processo de globalização. Apontamentos bibliográficos. En publicación: América Latina: cidade, campo e turismo. Amalia Inés Geraiges de Lemos, Mónica Arroyo, María Laura Silveira. CLACSO, Consejo Latinoamericano de Ciencias Sociales, San Pablo. Diciembre 2006. Disponível em: http://bibliotecavirtual.clacso.org.ar/ar/libros/edicion/lemos/08damiani.pdf. Acesso em: 20 ago. 2020.

DOMINGUES, Marcela Galizia. Análise dos impactos ambientais da instalação das unidades de bombeio de petróleo na área urbana de Mossoró-RN. (Dissertação de Mestrado em Geografia) Universidade Federal do Rio Grande do Norte. Centro de Ciências Humanas, Letras e Artes. Programa de Pós-Graduação em Geografia, Natal, 2014.

FIX, Mariana. Financeirização e transformações recentes no circuito imobiliário no Brasil. Tese (Doutorado em Desenvolvimento Econômico) - Instituto de Economia/Unicamp, Campinas, 2011.

FUNDAÇÂO JOAO PINHEIRO (FJP). Déficit habitacional no Brasil 2015: resultados preliminares. Belo Horizonte: FJP, 2017. 
GIL, Antônio Carlos. Métodos e técnicas de pesquisa social. 5. ed. São Paulo: Atlas, 1999.

HARVEY, David. Justiça social e a cidade. São Paulo: Hucitec, 1980.

. A produção capitalista do espaço. Tradução Carlos Szlak. Coordenação Antônio Carlos Robert Moraes. São Paulo: Annablume, 2005.

17 contradições e o fim do capitalismo. 1.ed. São Paulo: Boitempo, 2016.

IBGE. Instituto Brasileiro de Geografia e Estatística. Regiões de influência das cidades 2007. Rio de Janeiro: IBGE, 2008.

IBGE. Instituto Brasileiro de Geografia e Estatística. Censo Demográfico 2010. Resultados gerais da amostra. Rio de Janeiro: IBGE, 2012.

IBGE. Instituto Brasileiro de Geografia e Estatística - Cidades. Brasil em síntese, 2020. Disponível em: < https://cidades.ibge.gov.br/>. Acesso em: 10 ago. 2020.

IBGE. Instituto Brasileiro de Geografia e Estatística. Regiões de influência das cidades 2018. Rio de Janeiro: IBGE, 2019.

MOTTA, Diana; MATA, Daniel. Crescimento das cidades médias. Boletim Regional Urbano. Brasília: IPEA, n. 1, dez. 2008, p. 33-38. Disponível em: < http://repositorio.ipea.gov.br/handle/11058/5525>. Acesso em: 25 de ago. 2020.

MARICATO, Ermínia. "Moradia se tornou sinônimo de mercadoria", diz a ex-relatora da ONU Raquel Rolnik [16 de Agosto de 2016]. Brasil de Fato. Entrevista concedida à Camilla Hoshino e Thiago Hoshino. Diponível em: https://www.brasildefato.com.br/2016/08/16/moradia-se-tornousinonimo-de-mercadoria-diz-a-ex-relatora-da-onu-raquel-rolnik/. Acesso: 11 de ago. 2020.

MELAZZO, Everaldo Santos. Estratégias fundiárias e dinâmicas imobiliárias do capital financeirizado no Brasil. Mercator, Fortaleza, v. 12, n. 2, p. 29 a 40, sep. 2013. Disponível em:

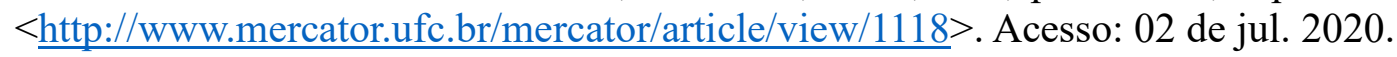

MELAZZO, E.S. Interações, combinações e sinergias: produção do espaço urbano, dinâmicas imobiliárias e o programa Minha Casa Minha Vida em cidades médias brasileiras. In: Urbanização, produção e consumo em cidades médias/intermediárias. Presidente Prudente:Universida Estadual Paulista; Lleda: Edicions de la Universitat de Lleida. 2015.

NASCIMENTO, E. A. Contradições e deficiências do Programa Minha Casa, Minha Vida: implicações e rebatimentos sobre a dinâmica socioespacial das cidades médias brasileiras. Revista Geographia, Niterói: UFF/EGG, Vol.16, n³2, pp. 68-89, 2014.

NEGRI, Sílvio Moisés. Segregação sócio-espacial: alguns conceitos e análises. Coletâneas do Nosso Tempo, Rondonópolis - MT, v. VII, nº 8, p. 129 a 153, 2008. 
POCHMANN, Márcio. Desempenho econômico conjuntural e a situação recente do trabalho no Brasil. Revista do Núcleo de Estudos de Economia Catarinense, v. 7, n. 13, p. 12-28, 2018.

ROCHA, Aristotelina Pereira Barreto. Expansão Urbana de Mossoró (período de 1980 a 2004): geografia dinâmica e reestruturação do território. Natal: EDUFRN, Editora da UFRN, 2005.

PINTO, Marina Barbosa. Questão habitacional como expressão da questão social na sociedade brasileira. Libertas, Juiz de Fora, v.4 e 5, n. especial, p.92 - 117, jan-dez/ 2004, jan-dez / 2005 - ISSN 1980-8518.

ROLNIK, Raquel. Guerra dos lugares. A colonização da terra e da moradia na era das finanças. $2^{\mathrm{a}}$ ed. São Paulo, Boitempo, [2015] 2019.

SANFELICI, Daniel. As escalas de acumulação na produção das cidades. In: A Cidade como negócio. CARLOS, Ana F. VOLOCHKO, Danilo. ALVAREZ Isabel P. (organizadores). São Paulo: Editora Contexto, 2015.

SHIMBO, Lúcia Zanin. Habitação social, habitação de mercado: a confluência entre Estado, empresas construtoras e capital financeiro. Tese (Doutorado em Arquitetura e Urbanismo) Faculdade de Arquitetura e Urbanismo, Universidade de São Paulo, São Carlos, 2010.

SILVEIRA, M.L. Globalização, trabalho, cidades médias. GeoUERJ, Rio de Janeiro, nº 11, p. 11-17. 2002.

SINGER, André. Raízes sociais e ideológicas do lulismo. Novos estud. - CEBRAP, São Paulo, n. 85, p. 83-102, 2009. Disponível em: $\leq$ http://www.scielo.br/scielo.php?script=sci_arttext\&pid=S010133002009000300004\&lng=en\&nr m=iso $\geq$. Acesso: 11 de nov. 2019.

SPOSITO, M. Encarnação Beltrão. O desafio metodológico da abordagem interescalar no estudo das cidades médias no mundo contemporâneo. Cidades. Presidente Prudente, v.3, n.5, p.143-157, 2006.

SOARES, Jamilson Azevedo. A juventude nos enredos da cidade, da cultura e do lazer: panis et circenses no 'país de Mossoró'? Tese (Doutorado em Geografia) - Universidade Federal de Pernambuco. Centro de Filosofia e Ciências Humanas. Programa de Pós-Graduação em Geografia, Recife, 2015. 270 p.

SOUZA, Marcelo Lopes de. A prisão e a ágora: reflexões em torno da democratização do planejamento e da gestão das cidades. Rio de Janeiro: Bertrand Brasil, 2006. 632 p.

SOUZA, Marcus V. M; LEITE, Myrelly L. R. Desigualdades socioespaciais e o Programa Minha Casa Minha Vida em Marabá (PA) Brazilian Geographical Journal: Geosciences and Humanities research medium, Ituiutaba, v. 8, n. 2, p. 45-62, jul./dez. 2017.

TOPALOV, C. Gananciais y Rentas Urbanas. Madrid, Siglo Veintiuno, 1984.

VASCONCELLOS, E. Por uma política nacional de transporte urbano. Revista dos Transportes Públicos nº 085 - ANTP, São Paulo, 2001. 
VIEIRA, Alexandre Bergamin. Poder Público e mercado imobiliário: os promotores da exclusão social em cidades médias. In: Egal 2009 - 12 Encuentro de Geógrafos de América Latina Programa online. 2009, Montevidéu. Resumos... Montévideu, 2009 Disponível em: http://www.observatoriogeograficoamericalatina.org.mx/egal12/Geografiasocioeconomica/Geografi aurbana/222.pdf. Acesso: 27 de ago. 2019. 